\title{
The mechanism of integration of the Ukrainian stock market in the world stock market
}

\author{
Anna Slobodianyk ${ }^{1}$, George Abuselidze ${ }^{2, *}$, and Lyudmyla Tarasovych $^{3}$ \\ ${ }^{1}$ National University of Life and Environmental Science of Ukraine, Heroiv Oborony, 11, 03041, \\ Kiev, Ukraine \\ ${ }^{2}$ Batumi Shota Rustaveli State University, Ninoshvili, 35, 6010, Batumi, Georgia \\ ${ }^{3}$ Zhytomyr National Agroecological University, Staryi Blvd, 7, 10008, Zhytomyr, Ukraine
}

\begin{abstract}
The article is devoted to structuring and improving the methodological foundations of the mechanism of state regulation of the stock market. Priority directions for the development of the stock market are determined in order to strengthen its role in stabilization of the national economy. As a result, a structural and functional model of stock market operation in the system of economic development of the country was elaborated. It involves ensuring the legitimate access of national companies to the global stock markets while attracting foreign investors to the Ukrainian stock market. The authors argue that the mechanism of the national stock market integration involves several stages: from enhancing international cooperation primarily with the stock markets of countries that are strategic partners, subsequent full participation in regional and subregional integration associations of stock markets, up to global integration in the world stock market as a priority direction for the development of the domestic stock market in the context of stabilization of the national economy.
\end{abstract}

\section{Introduction}

At present, economic growth requires sufficient financial resources for the restructuring of the economy. One of the real leverage of the country's economy is to attract investments, the most accepted and practical form of investing in securities through the stock market [2]. The trends of the modern world economy include the objective process of increasing the role of the stock market in the economic development of the country. In the present context of qualitative improvement of market relations, an important macroeconomic task of the stock market is related to the mobilization of disparate financial resources, their accumulation and transformation into productive capital. In order to effectively allocate financial resources to different sectors of the economy, to endure the financing of the state budget deficit, to improve the investment climate, to encourage stock exchanges to form integration structures with other stock market participants, as well as to achieve positive economic and social results, it is important to realize the potential of the stock market. For example, according to Demirguc-Kunt et al [10] as economies develop, banks increase their

* Corresponding author: george.abuselidze@bsu.edu.ge 
demand for the services provided by securities markets relative to those provided by banks, such that securities markets become increasingly important for future economic development. At the same time, author of the article considers the problems of globalization in financial markets and economic sovereignty in the context of the problem of interoperability, which is organically linked to the economic security of independent States [1]. The degree of integration of the domestic stock market to the world one is manifested in a high level of volatility, which determines its dependence on globalization processes in the world economy and indicates the need to improve the stock market infrastructure. The implementation of integration mechanisms is possible only provided that the priority directions of development of the Ukrainian stock market are substantiated based on the world experience.

\subsection{Problem statement}

At the present stage of economic transformations, it is important to determine the directions for the stock market development based on the basic principles of socioeconomic growth taking into account the best experience of countries with advanced and emerging economies, as well as to substantiate the expediency of institutional changes in state regulation of the domestic stock market. It is expedient to improve the theoretical and methodological approaches to assessing its functioning.

Research Questions The objectives of the study in accordance with these problems and relevance of the study are the following:

$\sqcup$ to develop methodological foundations of the mechanism of state regulation of the stock market;

$\sqcup$ to summarize the experience of stock markets operation in the countries with advanced and emerging economies;

$\sqcup$ to develop a structural and functional model of stock market operation in the system of the economic development of the country;

$\sqcup$ to identify priority directions for the development of the stock market in order to strengthen its role in stabilizing the national economy;

$\sqcup$ to improve approaches regarding the integration of the domestic stock market in the global stock market.

\subsection{Purpose of the Study}

The purpose of the study is to improve the theoretical and methodological foundations of the stock market operation in the system of economic development of the country and its integration in the world stock market.

\section{Research methods}

Theoretical and practical problems of integration and development of the stock market in the world stock market were investigated has been researched by such scientists, as Hsu, X. Tian, Y. Xu; H. Hong; T. Andersen, D. Dobrev, E. Schaumburg; U. Motorniuk, M. Terebukh, V. Kharchuk; O. Mohylevska, et al.,; B. Harrison, \& W. Moore; A. A. Erlikh, and others [5-7, 12-15, 18]. The set of methods and approaches was applied in the paper, which made it possible to realize the conceptual unity of the study. The experience of the stock markets operation in the countries with advanced and emerging economies is summarized. The main factors that constrain the development of the Ukrainian stock market are analysed in order to provide the main priority directions of the domestic stock 
market development in the context of globalization. Dialectical, structural and systemic methods were used to fully interpret the essence of the stock market in the system of economic development of the country. The experience of the stock markets operation of advanced and emerging economies was generalized by means of comparative, factor and statistical methods. Historical and logical approaches were used to determine the stages of formation and development of the stock market in Ukraine. Methods of scientific abstraction, synthesis and also economic and mathematical modelling were used to improve the methodological foundations of the functioning and further development of stock markets.

\section{Results and discussion}

Achieving sustainable economic growth, which is one of the basic strategic goals of developing national economies, objectively requires an adequate financial system capable of effectively transforming the temporarily free funds of organizations and the population into investments. The stock market is an important segment of the financial market as one of the components of the financial system of modern market economies, which is designed to facilitate the optimal and efficient allocation of financial resources between borrowers, creditors and investors.

By its economic origin, the securities market belongs to the group of specialized markets for functional purpose, which was formed in the second half of the twentieth century under the influence of the development of credit relations and joint-stock form of ownership. Historically, the functional purpose of the securities market has been and remains the promotion of investment capital from those who have free financial resources to those who need them. That is, in a market economy, securities markets are effective mechanisms for redistribution of investment resources, transformation of savings into investments $[3,4]$.

Investigating the ways to modernize the security of the national stock market of Ukraine, scientists note that, the securities market is an active part of the financial mechanism and one of the basic elements that makes it possible to somehow stabilize the course of economic and social processes in the life of society; it is associated with such basic essential features of the market as versatility, general nature, mass character, agility, activity, mobility, democracy, volatility, diversity and integrity (Table 1).

An analysis of the definitions "securities market" and "stock market" provided in the economic literature [8, 9, 17] suggests that as a rule, the authors do not mention considerable differences that would indicate fundamental substantive aspects of their essence. As a matter of fact, they reflect a virtually identical approach to understanding the essence of both the stock market and the securities market as a set of economic relations regarding the issue and circulation of securities as a specific commodity sold in a separate segment of the financial market.

From the standpoint of understanding the place of the stock market in the financial system of the country, it is quite useful to treat it as a mechanism of exchange. In this case, the stock market is a mechanism that ensures the movement of money funds from households that have savings to firms in need of investment and consists of a large number of various "channels" through which funds flow [20, 21].

It should be noted that a prerequisite for the full implementation of the set of functions that are interconnected and, as evidenced in practice, can be performed by one market entity, is the concerted joint activity of all elements that form the stock market infrastructure. At the same time, such consistency is the basis for ensuring the integrity of the market as an economic system and implies organizational centralization of conducting 
basic operations; within one country it can be embodied through creating a single national stock exchange, a single central depository of securities and a single clearing bank [16].

Table 1. Influence of the stock market on the socioeconomic stabilization.

\begin{tabular}{|c|c|c|}
\hline $\begin{array}{l}\text { Market } \\
\text { feature }\end{array}$ & Manifestation character & $\begin{array}{l}\text { Influence on the socioeconomic } \\
\text { stabilization }\end{array}$ \\
\hline Versatility & $\begin{array}{l}\text { Securities are a fictitious form of capital } \\
\text { (stock value) as well as a special } \\
\text { investment commodity, in certain cases } \\
\text { a kind of money substitute }\end{array}$ & $\begin{array}{l}\text { Different combinations of the use of } \\
\text { different securities make it possible to } \\
\text { realize certain goals and objectives of } \\
\text { socioeconomic development }\end{array}$ \\
\hline $\begin{array}{l}\text { General } \\
\text { nature }\end{array}$ & $\begin{array}{l}\text { Available in all types, spheres and } \\
\text { forms, levels of economic activity, in } \\
\text { all sectors and territories }\end{array}$ & $\begin{array}{c}\text { Provides a balanced flow of capital } \\
\text { between sectors, territories, types and } \\
\text { fields of activity }\end{array}$ \\
\hline $\begin{array}{l}\text { Mass } \\
\text { character }\end{array}$ & $\begin{array}{l}\text { Many participants and types of } \\
\text { securities, a large number of different } \\
\text { simultaneously carried out stock } \\
\text { transactions }\end{array}$ & $\begin{array}{l}\text { Attracting temporarily free financial } \\
\text { resources of domestic and foreign } \\
\text { potential investors }\end{array}$ \\
\hline Agility & $\begin{array}{l}\text { Rapid growth in the number of stock } \\
\text { market transactions, development of } \\
\text { various financial instruments and ever- } \\
\text { expanding diversified infrastructure }\end{array}$ & $\begin{array}{l}\text { Solution of certain problems of } \\
\text { investment support of socioeconomic } \\
\text { development }\end{array}$ \\
\hline Mobility & $\begin{array}{l}\text { Different technologies of stock market } \\
\text { transactions that are constantly updated. } \\
\text { Development of Internet-trading and } \\
\text { stock exchange trading in the online } \\
\text { mode }\end{array}$ & $\begin{array}{l}\text { Responding to news is instant, which } \\
\text { can both stabilize and destabilize } \\
\text { socioeconomic development }\end{array}$ \\
\hline Volatility & $\begin{array}{l}\text { High volatility due to simultaneous } \\
\text { influence of multidirectional factors } \\
\text { causes certain risk of investing in } \\
\text { securities }\end{array}$ & $\begin{array}{l}\text { Various fluctuations in the securities } \\
\text { market cause inevitable general } \\
\text { economic fluctuations that can lead to } \\
\text { catastrophic consequences and, } \\
\text { conversely, skillful regulation can } \\
\text { lead to positive changes } \\
\end{array}$ \\
\hline Activity & $\begin{array}{l}\text { Rapid response to political, economic } \\
\text { and social events }\end{array}$ & $\begin{array}{l}\text { Market sensitivity makes it possible } \\
\text { to track financial crises and upswing }\end{array}$ \\
\hline Democracy & $\begin{array}{c}\text { It gives real opportunities to potential } \\
\text { investors to freely choose investment } \\
\text { decisions }\end{array}$ & $\begin{array}{l}\text { Attracting investment to solve various } \\
\text { socioeconomic problems }\end{array}$ \\
\hline $\begin{array}{l}\text { Diversity and } \\
\text { integrity }\end{array}$ & $\begin{array}{c}\text { A variety of issuers and investors, } \\
\text { intermediaries, types of activities and } \\
\text { stock market transactions. Integrity of } \\
\text { primary and secondary, exchange and } \\
\text { extra-exchange, sectoral and regional } \\
\text { markets }\end{array}$ & $\begin{array}{l}\text { The multiplicity of forms and types of } \\
\text { transactions, participants of } \\
\text { transactions, types of securities makes } \\
\text { it possible to solve any problems of } \\
\text { socioeconomic development }\end{array}$ \\
\hline
\end{tabular}

Source: compiled by the authors according to [22]

Based on the analysis of the functions and tasks that infrastructure should perform if it is considered as an important component of the effective securities market operation, we propose the following definition: the securities market infrastructure is a complex subsystem of the securities market, the functional purpose of which is to ensure the effective pursuing of economic interests of issuers and investors through the organization of reasonable interaction of financial intermediation institutions, technical support, trade and information services in carrying out transactions with securities in order to ensure stable circulation of securities and accelerate the process of accumulation of investment resources.

Thus, the market infrastructure provides support for an optimal mode of reproduction and balanced development of individual markets. The emergence of stock market 
infrastructure is a natural process and a consequence of the manifestation of the division and specialization of social production in the financial field.

The market infrastructure, like the securities market itself, is a dynamic system functions and tasks of which are continuously expanding and changing in accordance with the main trends of development of the world and national securities markets, changes of moods and wishes of the main market participants - issuers and investors. The developed and branched infrastructure of the securities market lowers the level of transaction costs in the economic system.

World experience shows that an important factor in ensuring a country's economic growth is to increase investment by means of domestic savings. The savings, in turn, represent the use of savings for expanded production. Domestic savings are transformed into working capital with the help of the financial market [19]. The issues regarding the impact of the financial market (and its important component - the stock market) on the economic system and economic development of the country are ambiguous. To determine the place of the stock market in the system of economic development of the country, it is necessary to schematically show the process of transferring financial resources, capital between the participants of the stock market of the respective country (Fig. 1).

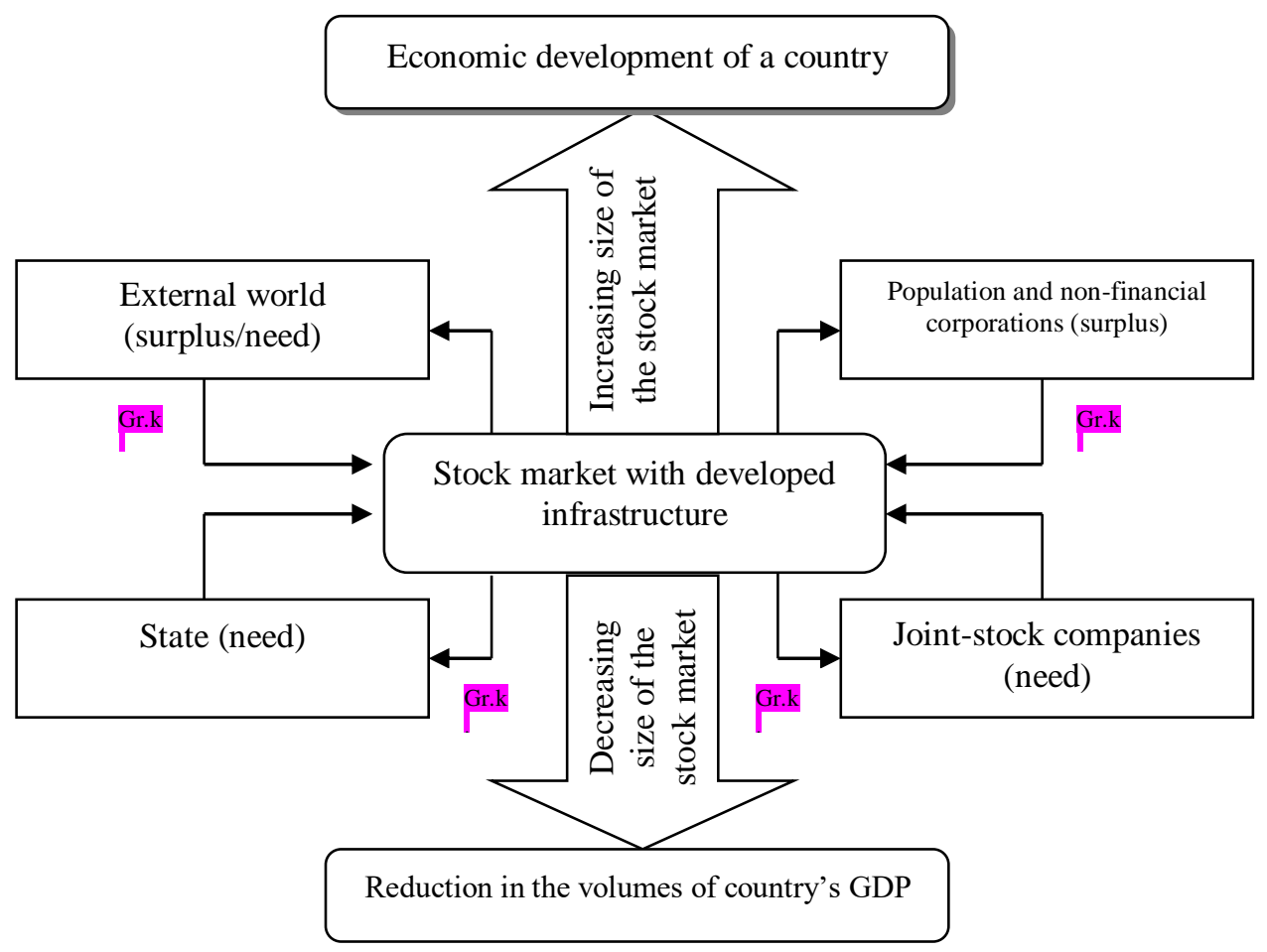

Fig. 1. Determining the place of the stock market in the general economic system of a country.

Source: compiled by the authors according to [11]

According to the system of national accounts, the whole economy is grouped into the following sectors: the state financed by taxes and the sale of own property; financial corporations, i.e. commercial institutional units specializing in financial services or auxiliary financial activities; non-financial corporations which include institutional units engaged in the market production of goods and services for sale at prices that cover the costs of production and produce a profit; households living on wages and other income; 
non-profit organizations that operate through contributions and donations and serve households; the external world (world economy). According to this scheme, the mediation of the stock market facilitates the accumulation, distribution and redistribution of financial resources, capital in the country's economy.

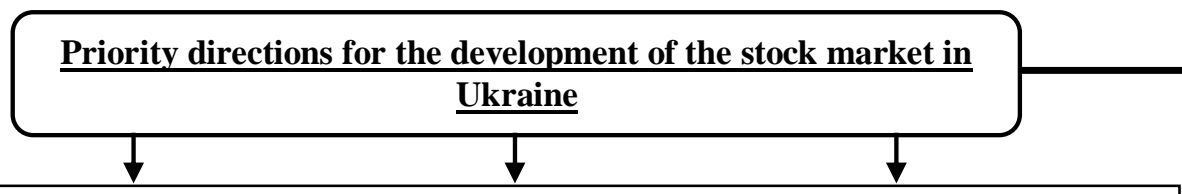

1. Increasing the competitive ability of the Ukrainian stock market (USM)

2. Recognition of the USM as a stock market of the emerging economy

3. Integration of the USM in the world stock market

Measures to implement the directions for the development of the Ukrainian stock market

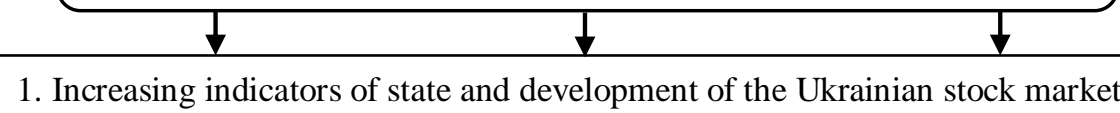

2. Enhancing the mechanism for the regulation of the USM

3. Developing the infrastructure of the Ukrainian stock market

4. Ensuring the security and transparency of the Ukrainian stock market

5. Ensuring integrating processes in the Ukrainian stock market

Main proposals to provide directions for the development of the stock market in Ukraine

1. Entry of national companies to the world stock markets

2. Attracting investors to the Ukrainian stock market

\section{Key outcomes of the implementation of the directions for the} development of the stock market in Ukraine

1. Increase in the capitalization and traded value in the USM
2. Gradual balanced integration of the Ukrainian stock market in the world stock
market
3.Positive influence on the country's economy as a result of attracting investment
in the real sector of economy of Ukraine

Fig.2. Scheme of the priority directions for the development of the Ukrainian stock market in the context of stabilization of the economy.

We believe that improving the competitive ability of the domestic stock market, civilized integration in the global stock market and recognition of the Ukrainian stock market as a stock market of the emerging economy should become priorities and main directions of the state policy in the context of strengthening its role in stabilizing the national economy. 
We also propose that in order to develop the stock market of Ukraine and achieve the set priorities, it is necessary to ensure a legitimate entry of national companies to the global stock markets while attracting foreign investors to the Ukrainian stock market. The general scheme of the stock market development in Ukraine is shown in Fig. 2.

Therefore, according to the substantiated scheme of priority directions for the development of the stock market in Ukraine, it is necessary to consider in more detail the main tasks, measures and proposals for the development of the Ukrainian stock market in the context of stabilization of the national economy.

The integration of the Ukrainian stock market in the world stock market is one of the main priority areas of market development in the context of strengthening its role in stabilizing the national economy.

In order to conduct a thorough and comprehensive study, this priority direction of the stock market development should be considered taking into account the following sequence: to determine the organizational and economic factors that affect the integration of the Ukrainian stock market as a result of internationalization processes; to investigate international cooperation and European integration of the Ukrainian stock market and its regulator; to substantiate an effective and balanced mechanism of gradual integration of the Ukrainian stock market; to substantiate the main directions and forms of entry of domestic enterprises to the world stock markets; to substantiate the attraction of foreign investors to the Ukrainian stock market.

The integration mechanism of the Ukrainian stock market in the world market is a set of constituent elements, factors, stages, forms and instruments, the interaction of which is aimed at the balanced development of the Ukrainian stock market in close connection with the world stock market. The integration mechanism consists of the following elements:

1. Organizational and economic factors that influence the process of integration of the Ukrainian stock market.

2. Stages of balanced integration of the Ukrainian stock market include enhancing the international cooperation; recognition of the Ukrainian stock market as a stock market of the emerging economy; participation of the stock market in integration associations.

3. Instruments of the integration of the Ukrainian stock market are the international cooperation, adaptation of international standards in the stock market of Ukraine, coordination of regulators, creation of a mega regulator, informational transparency of creating NETS, etc.

4. Forms of integration of the Ukrainian stock market are alliances, associations, full membership, etc.

Organizational and economic factors that influence the process of integration of national stock markets are a set of all possible practical measures and factors of organizational and economic nature that affect the process of integration of national stock markets in the global stock market in the context of globalization of the world economy. Accordingly, at the present stage, it is necessary to develop an effective, well-substantiated mechanism for the gradual balanced integration of the Ukrainian stock market in the global stock market in order to ensure the main priority directions for the development of the domestic stock market in the context of globalization (Fig. 3). 


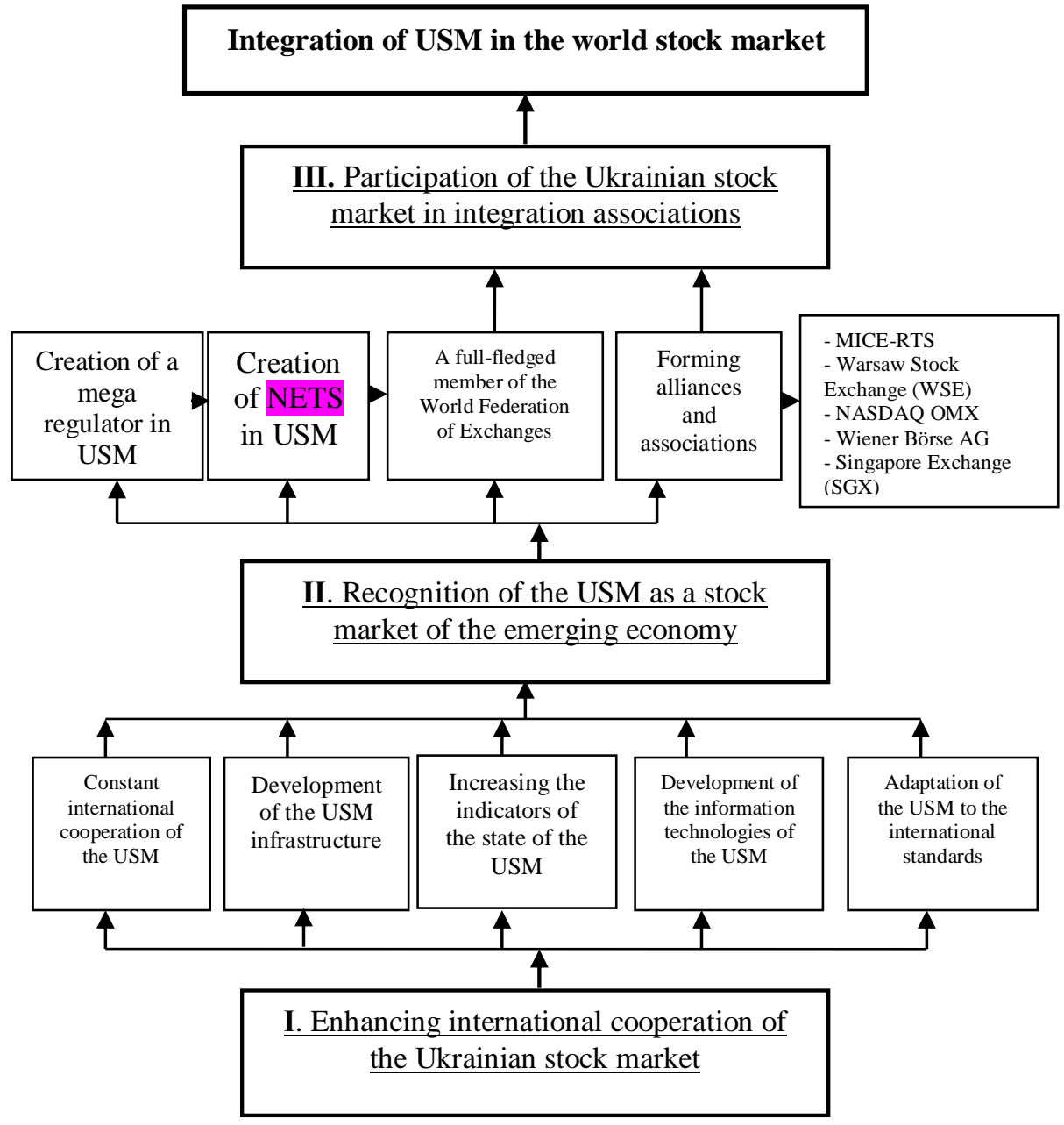

Fig. 3. Mechanism of the stage-by-stage integration of the Ukrainian stock market in the world stock market.

The mechanism of the integration of the national stock market involves a number of stages: from enhancing international cooperation primarily with the stock markets of countries that are strategic partners, subsequent full participation in regional and subregional integration associations of stock markets, up to global integration in the world stock market as a priority direction for the development of the domestic stock market in the context of stabilization of the national economy. After all, the Ukrainian stock market should become an integral part of the global stock market, providing foreign investors with a reliable mechanism for making portfolio investments in the economy of Ukraine.

\section{Conclusions}

In our opinion, considering the priority directions of the development of the stock market in Ukraine in the context of stabilization of the national economy, in order to attract foreign investors to the domestic stock market, it is necessary to take measures to activate the national stock market, which is aimed at active attraction of local investors to the market and solution of the problem of the deficit of securities with high investment characteristics 
in Ukraine. To consider the possibility of attracting a much larger number of foreign investors to the national stock market in the presence of development and implementation of a mechanism for circulation of securities of foreign issuers in Ukraine. To develop adequate price setting for securities of foreign issuers in the stock market of Ukraine (lack of adequate price is a significant risk factor for foreign investors and has negative consequences for domestic stock market). To expand the list of instruments for investing in Ukraine with the possibility to diversify assets, which is relevant both for domestic and international institutional investors and should lead to an increase in portfolio investment, which is as important in attracting capital to Ukraine as direct foreign investment. To develop the Ukrainian stock market with the corresponding infrastructure according to the international standards. To stimulate the internal demand for a new type of stock instrument (securities of foreign issuers), which will lead to an increase in the level of liquidity of the national stock market.

Therefore, in order to ensure priority directions for the formation of the stock market in Ukraine, it is primarily necessary to consider the organizational and economic factors that affect the integration of the Ukrainian stock market as a result of the process of internationalization, and also to determine the main directions for domestic companies to enter the world stock markets and attract foreign investors to the stock market of Ukraine.

\section{References}

1. G. Abuselidze, Conference Globalization and Sustainable Economic Development Prospects (2012) doi:10.2139/ssrn.3194654

2. G. Abuselidze, Journal of Applied Economic Sciences, 13, 7 (2018)

3. G. Abuselidze, L. Beridze, Proceedings of the 4th International Conference on European Integration, 29-41 (2018)

4. G. Abuselidze, A. Slobodianyk, Economic Science for Rural Development Conference Proceedings, 52 (2019)

5. G. Abuselidze, O. Mohylevska, et al., SHS Web of Conferences, 67, EDP Sciences (2019) doi:10.1051/shsconf/20196706001

6. G. Abuselidze, M. Kizinidze, E3S Web of Conferences, 135, EDP Sciences (2019) doi:10.1051/e3sconf/201913504037

7. T. Andersen, D. Dobrev, E. Schaumburg, Integrated quarticity estimation: Theory and practical implementation (John Wiley \& Sons, 2012)

8. C. Bourne, Trust, power and public relations in financial markets (Routledge, 2016) doi.10.4324/9781315867526

9. W. I. Chuang, B. S. Lee, Journal of Financial Markets, 14, 3 (2011) doi:10.1016/j.finmar.2010.12.001

10. A. Demirguc-Kunt, E. Feyen, R. Levine, World Bank Economic Review, 27, 3 (2013) doi:10.1093/wber/lhs022

11. A. Elder, Basics of stock trading. Training manual for bidders on world exchanges (Diagram, 2008)

12. A. A. Erlikh, Technical Analysis of Commodity and Financial Markets (INFRA-M, 1996)

13. B. Harrison, W. Moore, Journal of Forecasting, 31, 6 (2012) doi.org/10.1002/for.1214

14. H. Hong, J. Wang, The Journal of Finance, 55, 1 (2007) doi:10.1111/0022-1082.00207 
15. P. H. Hsu, X. Tian, Y. Xu, Journal of Financial Economics, 112, 1 (2014) doi:10.1016/j.jfineco.2013.12.002

16. http://repository.fue.edu.eg/xmlui/bitstream/handle/123456789/2732/6964.pdf?sequenc $\mathrm{e}=1$

17. doi.10.23943/princeton/9780691133539.001.0001

18. U. Motorniuk, M. Terebukh, V. Kharchuk, Econtechmod. An International Quarterly Journal, 5, 1 (2016)

19. Neyman, E.L., Small Trader's Encyclopedia (VIRA-R Alpha Capital, 1999)

20. W. J. O'Neil, W. J. O'Neil, How to make money in stocks (McGraw-Hill, 10, New York, 1988)

21. W. J. O'Neil, G. Morales, How to make money selling stocks short (John Wiley \& Sons, 2004)

22. J. Wiley, An Introduction to Equity Markets (The Reuters Financial Training Series, 2001) 